\title{
Bio-physicochemical markers of the Aedes aegypti breeding water in endemic and non-endemic area
}

\author{
Nurul Hidayah ${ }^{1}$, Dwi Rahmawati ${ }^{2}$ \\ ${ }^{1}$ Department of Health Promotion, Health Faculty, Sari Mulia University, Indonesia \\ ${ }^{2}$ Department of Midwifery, Health Faculty, Sari Mulia University, Indonesia
}

\section{Article Info \\ Article history: \\ Received Mar 18, 2019 \\ Revised Apr 10, 2019 \\ Accepted May 16, 2019}

\section{Keywords:}

Aedes aegypti

Dissolved oxygen

$\mathrm{pH}$

Salinity

Temperature

\begin{abstract}
The survival of Aedes aegypti larvae is inseparable from the adequacy of food, including organic substances available in the breeding water. It is very dependent on the level of water markers such as temperature, salinity, Dissolved Oxygen, and $\mathrm{pH}$. The study used quantitative observational analytic with a case control study design. Case group was consisted of breeding water in endemic area and control group was in non-endemic area. The sample size was 43 samples for each group, collected by purposive sampling technique. Data were analyzed by Chi-square and Mann-Whitney test. Larvae mostly presence in endemic area $(68.3 \%)$ and mostly absent in non-endemic area $(85.4 \%)(p$-value $=0.002)$. Temperature in endemic area mostly in $27-30^{\circ} \mathrm{C}(86 \%)$ and non-endemic area mostly in $<27^{\circ} \mathrm{C}$ or $>30^{\circ} \mathrm{C}(72.1 \%)(p$-value $=0.000)$. Salinity in endemic and non-endemic areas has no difference ( $p$-value $=0.266)$. DO in endemic areas were mostly in $5.02-7.82 \mathrm{mg} / 1(76.7 \%)$. While DO in non-endemic area was mostly in $<5.02$ $\mathrm{mg} / \mathrm{l}$ or $>7.82 \mathrm{mg} / \mathrm{l}(95.3 \%)(p$-value $=0.001)$. The $\mathrm{pH}<6$ or $>7.8$ is mostly in non-endemic areas $(87.8 \%)$ and $\mathrm{pH}$ 6-7.8 is mostly in endemic areas $(63.4 \%)$ $(p$-value $=0.000)$. Bio-physicochemical markers of breeding sites water have differences between endemic and non-endemic area except salinity. The temperature, salinity, DO, and $\mathrm{pH}$ affected the presence of larvae and the most affected is DO marker. While the marker that affected the presence of larvae in non-endemic area is $\mathrm{pH}$.
\end{abstract}

Copyright () 2019 Institute of Advanced Engineering and Science. All rights reserved.

\section{Corresponding Author:}

Nurul Hidayah,

Department of Health Promotion, Health Faculty,

Sari Mulia University,

Jl. Pramuka No. 2, Kelurahan Pemurus Luar, Kota Banjarmasin 70436.

Email: hiragi_12@yahoo.com

\section{INTRODUCTION}

Dengue Hemorrhagic Fever (DHF) is a potentially fatal disease that is transmitted through the Aedes mosquito vector carrying the dengue virus. The World Health Organization (WHO) data shows that Indonesia has the highest incidence of DHF among Southeast Asian countries [1-2]. The incidence of this serious disease in Indonesia is known to fluctuate. The incidence of DHF was 77.96 per 100,000 population in 2016 and 22.55 per 100,000 populations in 2017, while the DHF mortality rate was 0.79 in 2016 and 0.75 in 2017. South Kalimantan province experiences some incidence of DHF every year, with especially serious outbreaks in several outbreak areas. In 2015 and 2016, all regencies and cities in the province experienced some incidence of DHF (100\%), but this decreased slightly to $92.31 \%$ in 2017 . One district that has consistently experienced DHF over the last 3 years is Banjar Regency [3-4]. Banjar Regency consists of 19 districts. Martapura District is an endemic area with the highest dengue incidence rate of 98.0 per 100,000 population in 2016 and 71.7 per 100,000 population in 2017 [5-6]. 
Data shows that DHF is an urgent problem that requires the implementation of control measures so that the incidence of infection does not increase. One approach involves breaking the chain of transmission by controlling the prevalence of the vector $A$. aegypti. It is known that the pre-mature breeding places for A. aegypti (larvae) are located in water reservoirs. Damanik's research [7] identified the highest average number of larvae (68.89) as occurring in well water. This shows that the most favored A. aegypti mosquito breeding location is in well water. The survival of $A$. aegypti larvae is highly dependent on the availability of nutrients, including organic substances available in breeding water. Thus, its survival is extremely dependent on breeding water quality [7].

Water quality, as measured through observation of various chemical and physical markers, is one of the important factors determining the survival of living organisms in water. One of the physical markers that play an important role in the development of the DHF vector is temperature [8]. Damanik's study [7] found that the optimal water temperature of a breeding site was $27.6^{\circ} \mathrm{C}$; at this temperature, the average abundance of A. aegypti larvae was found to be the highest. This finding was confirmed by Afolabi, et al. [9], who found that water temperatures at $A$. aegypti breeding sites typically fell within the range of $26.5^{\circ} \mathrm{C}-29.3^{\circ} \mathrm{C}$.

In addition to physical markers, several water chemistry markers have also been shown to influence the development of $A$. aegypti larvae. These include salinity and Dissolved Oxygen (DO), which have been proven to have a significant relationship with the development of A. aegypti larvae. Based on the results of Rao's research [10] on the characteristics of breeding sites, salinity has a significant correlation with the presence of $A$. aegypti larvae. In addition to salinity and $\mathrm{DO}, \mathrm{pH}$ is also thought to influence the presence of larvae [10].

The $\mathrm{pH}$ level of water quantifies its degree of acidity or basicity. The $\mathrm{pH}$ scale ranges from 0 to 14 ; if the $\mathrm{pH}$ value is less than 7 , it indicates an acidic environment, while a value above 7 indicates a basic environment [11]. The results of Gopalakhrisnan's study [12] showed that the average percentage of larvae that developed into mosquitoes in water with $\mathrm{pH} 5$ was $76.5 \%$, while the percentage for $\mathrm{pH} 7$ was $98 \%$, and the percentage for $\mathrm{pH} 9$ was $86.5 \%$.

These findings demonstrate the possible influence of temperature, salinity, DO, and water $\mathrm{pH}$ on the proliferation of mosquito vectors. Therefore, if appropriate measures are to be taken in order to control DHF in Banjar Regency, South Kalimantan Province, there is clearly a need for research into the effects of temperature, salinity, DO, and $\mathrm{pH}$ levels of $A$. aegypti breeding water on larvae in endemic and non-endemic DHF areas there.

\section{RESEARCH METHOD}

This study used quantitative, observational, and analytic methods with a case-control study design. The case group was an aquatic breeding site located in an endemic area, while the control group was located in a non-endemic area. The sample used in this study consists of breeding sites located throughout Banjar Regency, South Kalimantan Province, Indonesia. Tanjung Rema Darat Village was selected as the site for the case group because it has the highest DHF incidence. The sample for the control group was taken from a breeding site located in Tanah Abang Village. Samples were taken by a purposive sampling technique from about 86 households, or 43 households for each group.

Visual observations of water breeding sites were conducted to obtain the data measuring larvae presence. Water samples were taken using a dipper, then stored in bottles. Samples were then stored in a cooler box. Data collection of larvae presence, temperature $\left({ }^{\circ} \mathrm{C}\right)$, and $\mathrm{pH}$ markers took place directly in the field, while salinity and dissolved oxygen data were measured in environmental health laboratories. Well water was the type of $A$. aegypti breeding water which was studied. Bio-physicochemical markers of breeding water were categorized based on previous research. The larvae presence categories were defined as in Hidayah's research [13], that is, as "found" and "not found", or "present" and "absent".

The temperature and Dissolved Oxygen were categorized based on Sanchez's study [14]. The categories for temperature are " $27-30^{\circ} \mathrm{C}$ ", and "less than $27^{\circ} \mathrm{C}\left(<27^{\circ} \mathrm{C}\right)$ or $>30^{\circ} \mathrm{C}$ ". Dissolved Oxygen are categorized as " $5.02-7 \mathrm{markamg} / \mathrm{l}$ " or " $<5.02 \mathrm{mg} / \mathrm{l}$, or $>7.82 \mathrm{mg} / \mathrm{l}$ ". The salinity categories, defined based on Anggraini's research [15], are "4-6 gr/l", and " $<4$ gr/l or $>6$ gr/l". Water $\mathrm{pH}$ levels are categorized as either "less than $6(<6)$ or $>7.8$ " or " $6-7.8$ ". This categorization is based on the results of Ridha's study [16], which found that the average $\mathrm{pH}$ value of a positive water reservoir containing larvae is $\mathrm{pH}$ 6-7.8. Data were analyzed by Chi-square test to determine the effects of the water markers on larvae existence, and then Logistic Regression tests were used to identify the dominant parameters in each group. The differences between each marker for endemic and non-endemic areas are analyzed using the Mann-Whitney test. 


\section{RESULTS AND DISCUSSION}

\subsection{Characteristic of breeding sites}

Characteristics of $A$. aegypti mosquito breeding sites include color, the presence or absence of a lid, and the location of the water container. These are presented for sites from endemic and non-endemic DHF areas in Table 1.

Table 1. Characteristics of Aedes aegypti mosquito breeding sites and the effect on larvae presence in endemic and non-endemic area

\begin{tabular}{|c|c|c|c|c|c|}
\hline \multirow{2}{*}{ Characteristic } & \multicolumn{2}{|c|}{ Endemic area } & \multicolumn{2}{|c|}{ Non-endemic area } & \multirow{2}{*}{$\begin{array}{c}\mathrm{p}- \\
\text { value }\end{array}$} \\
\hline & $\mathrm{n}$ & $\%$ & $\mathrm{n}$ & $\%$ & \\
\hline \multicolumn{6}{|l|}{ Color } \\
\hline Dark & 30 & 69.8 & 7 & 16.3 & 0.001 \\
\hline Bright & 13 & 30.2 & 36 & 83.7 & $(<0.05)$ \\
\hline Total & 43 & 100 & 43 & 100 & \\
\hline \multicolumn{6}{|l|}{ Lid existence } \\
\hline Not exist & 27 & 62.8 & 5 & 11.6 & 0.000 \\
\hline Exist & 16 & 37.2 & 38 & 88.4 & $(<0.05)$ \\
\hline Total & 43 & 100 & 43 & 100 & \\
\hline \multicolumn{6}{|l|}{ Position } \\
\hline Outside & 3 & 6.9 & 14 & 32.6 & 0.711 \\
\hline Inside & 40 & 93.1 & 29 & 67.4 & $(>0.05)$ \\
\hline Total & 43 & 100 & 43 & 100 & \\
\hline
\end{tabular}

Table 1 shows that the breeding sites for A. aegypti mosquitoes in endemic areas are mostly dark in color $(69.8 \%)$, do not have a lid $(62.8 \%)$, and are located indoors $(93.1 \%)$. Breeding sites in non-endemic areas mostly share bright colors $(83.7 \%)$, have a lid $(88.4 \%)$, and are located indoors $(67.4 \%)$. Statistically, the color characteristics and the presence of the lid have significant differences, while the positions of the breeding sites do not.

\subsection{Larvae presence in endemic and non-endemic area}

Observations of larvae in each area show that larvae are typically present in endemic areas (68.3\%), while larvae are usually absent in non-endemic area (85.4\%) as shown in Figure 1.

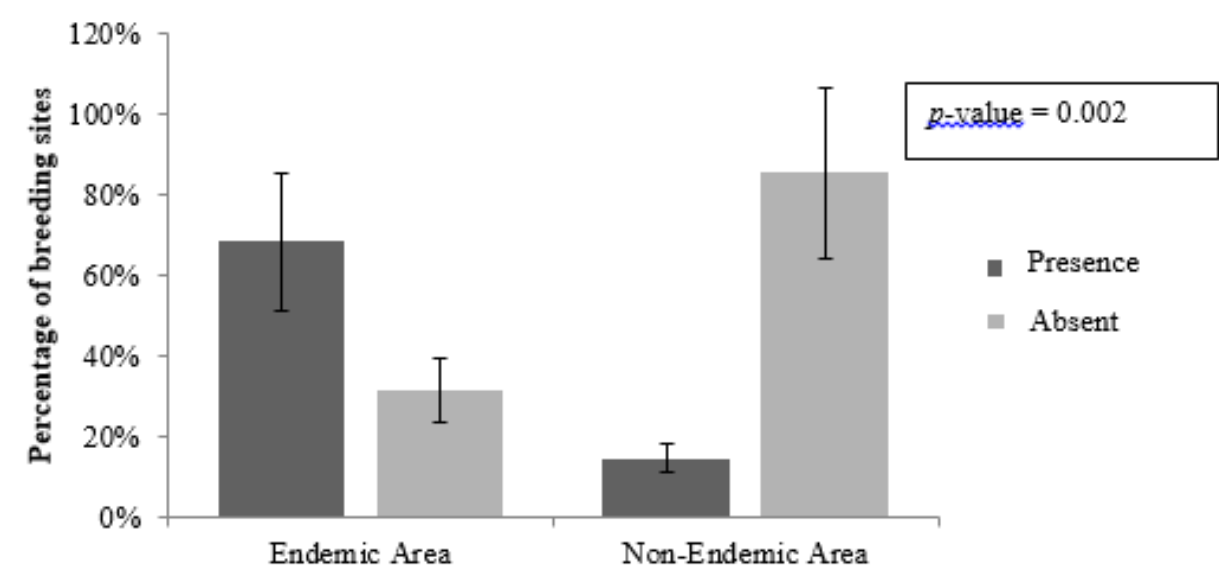

Figure 1. The comparison of larvae presence in endemic and non-endemic areas

\subsection{Temperature marker in endemic and non-endemic area}

A comparison of statistical descriptors (mean \pm SD) of temperature data for endemic and non-endemic area is presented in Table 2. The results of a normality test showed that the temperature parameters were not normally distributed, and so they could not be analyzed by the parametric independent t-test. An appropriate alternative test is thus given by non-parametric Mann-Whitney test. The percentage comparison of temperature marker based on categories " $27-30^{\circ} \mathrm{C}$ " and " $\angle 27^{\circ} \mathrm{C}$ or $>30^{\circ} \mathrm{C}$ " showed that temperature in endemic areas mostly fell within the range $27-30^{\circ} \mathrm{C}(86 \%)$. The temperatures in non-endemic 
areas were mostly in “ $<27^{\circ} \mathrm{C}$ or $>30^{\circ} \mathrm{C}$ " ranges $(72.1 \%)$. The temperatures between endemic and non-endemic areas differed significantly, with p-value $=0.000$ as shown in Figure 2.

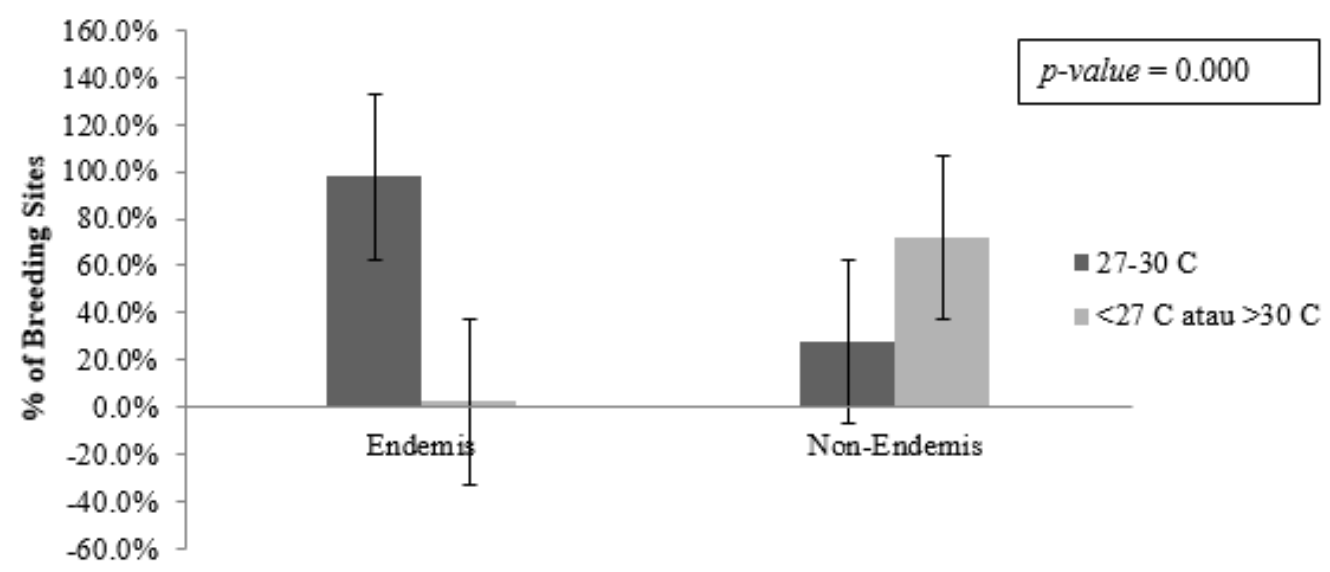

Figure 2. The comparison of temperature in endemic and non-endemic areas

Water temperature is very influential on larvae proliferation, since generally larvae prefer warm places. That is why Aedes sp. is more common in the tropics. The time of hatching of an egg depends on the water temperature to a certain extent; an egg developing in warmer temperatures will hatch faster to become an instar. Results showed that at a temperature of $20^{\circ} \mathrm{C}$, eggs hatched within 3.5 days, whereas if the temperature was raised to a temperature of $35^{\circ} \mathrm{C}$, the eggs hatched within 2 days.

\subsection{Salinity marker in endemic and non-endemic area}

A comparison of statistical descriptors (mean $\pm \mathrm{SD}$ ) salinity data for endemic and non-endemic areas is presented in Table 2. Salinity data for endemic and non-endemic areas are not normally distributed. Statistical tests yielded a p-value of 0.266 . This shows that there is no significant difference in salinity between endemic and non-endemic areas. Salinity in endemic areas mostly falls in the category of "4-6 gr/l" $(65.1 \%)$, as is also the case in endemic areas $(83.7 \%)$.

Table 2. Statistic scores and the effect of temperature, salinity, Dissolved Oxygen (DO), and pH on larvae presence in endemic and non-endemic area

\begin{tabular}{ccccc}
\multicolumn{5}{c}{ presence } \\
\hline Statistic score & Endemic area & p-value & Non-endemic area & p-value \\
\hline Temperature $\left(\mathrm{C}^{\circ}\right)$ Mean \pm SD & $27.51 \pm 0.798$ & $0.002(<0.05)$ & $25.70 \pm 1.124$ & $0.093(>0.05)$ \\
Salinity $(\mathrm{gr} / \mathrm{l})$ Mean \pm SD & $4.058 \pm 0.927$ & $0.000(<0.05)$ & $4.472 \pm 1.365$ & $0.075(>0.05)$ \\
DO (mg/l) Mean \pm SD & $6.393 \pm 1.143$ & $0.019(<0.05)$ & $7.253 \pm 1.099$ & $0.080(>0.05)$ \\
pH Mean \pm SD & $6.527 \pm 0.909$ & $0.001(<0.05)$ & $5.499 \pm 0.659$ & $0.004(<0.05)$ \\
\hline
\end{tabular}

Salinity is a measure expressed by the amount of salts dissolved in a volume of water. The amount of salts dissolved in water determines the level of salinity [17]. Research by Rao [10] and Anggraini [15] found a significant relationship between salinity and larva density. In addition, the results also show that temperature, $\mathrm{DO}$, and $\mathrm{pH}$ in endemic areas are very conducive for mosquito breeding. This causes more larvae to be found in endemic areas than in non-endemic areas. The survival of Aedes aegypti larvae is dependent on the abundance of food, including organic substances available in the breeding water. It is thus very dependent on the level of water markers such as temperature, $\mathrm{pH}$, salinity, and Dissolved Oxygen.

\subsection{Dissolved oxygen marker in endemic and non-endemic area}

The statistic score (mean $\pm \mathrm{SD}$ ) for dissolved oxygen markers for endemic and non-endemic areas are presented in Table 2. Based on the mean value, it is known that DO markers in endemic areas are lower than in non-endemic areas. The data obtained were normally distributed, and statistical tests produced a $p$-value of 0.001. There are thus significant differences in DO between endemic and non-endemic areas. Dissolved Oxygen markers were categorized into 2 groups. They are "5.02-7.82 $\mathrm{mg} / \mathrm{l}$ " and " $<5.02 \mathrm{mg} / \mathrm{l}$ or $>7.82 \mathrm{mg} / \mathrm{l}$ ". DO levels in endemic areas were mostly in the category "5.02-7.82 mg/l" 
(76.7\%). Meanwhile, DO levels in non-endemic areas were mostly in the category " $<5.02 \mathrm{mg} / \mathrm{l}$ or $>7.82 \mathrm{mg} / \mathrm{l} "(95.3 \%)$ as shown in Figure 3.

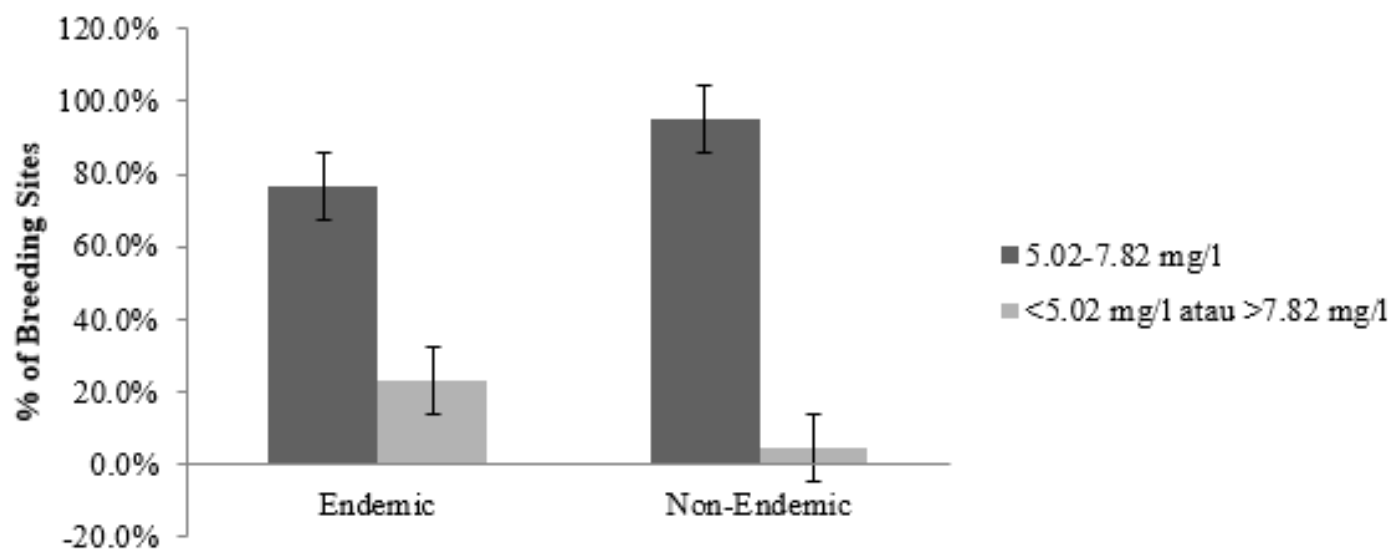

Figure 3. The comparison of DO marker in endemic and non-endemic area

Larvae are also influenced by dissolved oxygen (DO). DO levels which support larval breeding are those in which there is sufficient dissolved oxygen to meet the oxygen requirements of the larvae in the water reservoirs, and also serve as a marker that food sources for larvae are available. Dissolved oxygen levels in water depend on the amount of vegetation in the water. This is because the vegetation in the waters conducts photosynthesis. The photosynthesis process will affect the presence of dissolved oxygen (DO) in water, which in turn will affect the density of mosquito larvae at the breeding site [18].

Dissolved oxygen is needed by all living bodies for breathing, metabolic processes, or for the exchange of substances which then produce energy for growth and breeding. In addition, oxygen is also needed for the oxidation of organic and inorganic materials in the aerobic process [19]. Several studies that are in line with this research include Rao [10], Gopalakrishnan [12], Sanchez [14], and Olayemi [20]. These studies have proven that DO has a positive influence on the presence of larvae; the higher the DO levels of the breeding water, the more larvae are found there.

\section{6. $\mathrm{pH}$ marker in endemic and non-endemic area}

Statistical descriptors of $\mathrm{pH}$ marker data including mean \pm SD values are presented in Table 2 . $\mathrm{PH}$ levels in endemic and non-endemic areas were not normally distributed, so they were categorized into "pH 6-7.8" and " $<6$ or $>7.8$ " groups. Levels of $\mathrm{pH} 6-7.8$ are mostly found in endemic areas $(63.4 \%)$ compared to non-endemic areas (12.2\%). The highest occurrences of $\mathrm{pH}$ " $<6$ or $>7.8$ " sites were in non-endemic areas $(87.8 \%)$ as opposed to endemic areas $(36.6 \%)$ as shown in Figure 4.

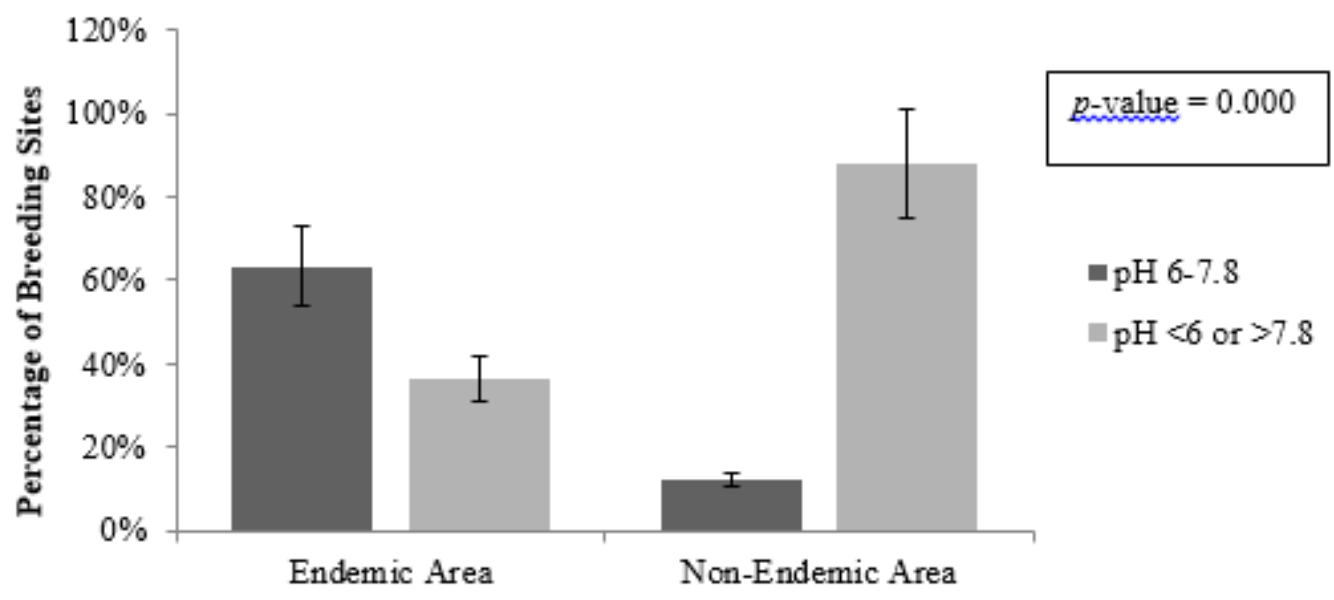

Figure 4. The comparison of $\mathrm{pH}$ level in endemic and non-endemic area 
Statistically, temperature, salinity, DO, and $\mathrm{pH}$ markers affect the presence of larvae in endemic areas. The most influential marker is Dissolved Oxygen. Breeding water with DO in the category "5.02-7.82 mg/l" has a risk of larvae 3 times greater than water with DO in the category " $<5.02 \mathrm{mg} / \mathrm{l}$ or 7.82 $\mathrm{mg} / \mathrm{l}$ " $(\mathrm{OR}=3.00)$. The only marker that significantly affects larvae presence in non-endemic areas is $\mathrm{pH}$; other markers do not significantly affect the presence of larvae as shown in Table 2.

Besides this, water with $\mathrm{pH}$ that is too acidic or too alkaline will easily result in dead larvae. The levels of $\mathrm{pH}$ that are too acidic are thought to inhibit plankton growth. Plankton is one of the primary food sources for mosquito larvae, and a reduction in this food source reduces the larvae's chances of sustaining life. These results are in agreement with the results of previous studies, including those of Umar and Donpedro in Rao [10], Ridha [16], Olayemi [20], Thangamathi [21], and Madzlan [22]. Both pH and temperature affect larvae density. The $\mathrm{pH}$ and temperature levels are positively associated with larvae density. This is because $\mathrm{pH}$ and temperature have an impact on mosquitoes associated with osmoregulation and oxygen transport.

\section{CONCLUSION}

Bio-physicochemical markers of water samples from breeding sites show significant differences between endemic and non-endemic DHF areas, except in terms of salinity. The temperature, salinity, DO, and $\mathrm{pH}$ significantly affected the presence of larvae, with the DO marker showing the greatest affect. The marker that most affected the presence of larvae in non-endemic areas was $\mathrm{pH}$.

\section{ACKNOWLEDGEMENTS}

This research was supported by Ministry of Research, Technology, and Higher Education in the scheme of beginner lecturer research grant 2018.

\section{REFERENCES}

[1] Guzman A, Isturiz RE. Update on the global spread of dengue. International of Journal Antimicrobial Agents. Vol. 36: S40-S42. 2010

[2] World Health Organization. Comprehensive guidelines for prevention and control of dengue and dengue haemorrhagic fever. Revised and Expanded Edition. www.apps.searo.who.int. 2011.

[3] Ministry of Health of the Republic of Indonesia. Data and Information, Indonesian Health Profile (in Bahasa: Kementerian Kesehatan Republik Indonesia. Data dan Informasi, Profil Kesehatan Indonesia. Kemenkes RI. 2016.

[4] Ministry of Health of the Republic of Indonesia. Data and Information, Indonesian Health Profile (in Bahasa: Kementerian Kesehatan Republik Indonesia. Data dan Informasi, Profil Kesehatan Indonesia. Kemenkes RI. 2017.

[5] Banjar District Health Office. Health Profile of Banjar Year 2016. Distric Health Office 2016 (in Bahasa: Dinas Kesehatan Kabupaten Banjar Profil Kesehatan Kabupaten Banjar Tahun 2016. Dinkes Kab. Banjar. 2016.

[6] Banjar District Health Office. Health Profile of Banjar Year 2017. Distric Health Office 2017 (in Bahasa: Dinas Kesehatan Kabupaten Banjar Profil Kesehatan Kabupaten Banjar Tahun 2017. Dinkes Kab). Banjar. 2017.

[7] Damanik, Dewi D. 2012. The Most Favored Breeding Site for Aedes aegypti Mosquitoes by Type of Water Source (in Bahasa: Tempat Perindukan yang Paling Disenangi Nyamuk Aedes aegypti Berdasarkan Jenis Sumber Air). Medan: Universitas Sumatera Utara.

[8] Khoiriyah, Rahayu Astuti, Sayono. 2010. Differences in Physical and Chemical Parameters of Breeding Water Based on the Aedes aegypti Larvae in Semarang City (in Bahasa: Perbedaan Parameter Fisika dan Kimia Air Perindukan Berdasarkan Keberadaan Jentik Aedes aegypti di Kota Semarang). Semarang: Universitas Muhammadiyah Semarang.

[9] Afolabi O. J., Simon-Oke I. A., Osomo B. O. 2013. Distribution, Abundance and Diversity of Mosquitoes in Akure, Ondo State, Nigeria. Journal of Parasitology and Vector Biology. 2013; Vol. 5(10): 132-136.

[10] Rao, B. Bhaskar, PS Harikumar, T. Jayakrishnan and B. George. Characteristics of Aedes (Stegomya) Albopictus Skuse (Diptera: Culicidae) Breeding Sites. Southeast Asian J Trop Med Public Health. 2011; Vol. 42(5): 10771082.

[11] Kasetyaningsih, T., Sundari, S. 2007. Difference Between House Index Involving Well Inspection in the Dengue Vector Survey in Pepe Bantul Hamlet (in Bahasa: Perbedaan Antara House Index yang Melibatkan Pemeriksaan Sumur pada Survei Vektor Dengue di Dusun Pepe Bantul”. Jurnal Kedokteran YARSI. Yogyakarta. $2006 ; 14$ (1): 034-037.

[12] Gopalakrishnan, Das M., Baruah I., Veer V., Dutta P. 2013. Physicochemical Characteristics of Habitats in Relation to the Density of Container-Breeding Mosquitoes in Asom, India. J Vector Borne Dis. 2013; Vol. 50 (3): 215-9. 
[13] Hidayah, N., Iskandar, Abidin, Z. Prevention of Dengue Hemorrhagic Fever (DHF) Associated with the Aedes aegypti Larvae Presence based on the Type of Water Source. Journal of Tropical Life Science, [S.1.], v. 7, n. 2, p. 115-120, June 2017. ISSN 2527-4376.

[14] Sanchez, D. C. G., Pinilla, G.A., Quintero, J. Ecological characterization of Aedes aegypti larval habitats (Diptera: Culicidae) in artificial water containers in Girardot, Colombia. Journal of Vector Ecology. July 2017. Vol. 42, No. 2: $289-297$

[15] Anggraini, T. S., Cahyati, W. H. Perkembangan Aedes aegypti pada berbagai $\mathrm{pH}$ air dan salinitas air. Higeia Journal of Public Health Research and Development. Juli 2017. Vol 1, No. 3: 1-10.

[16] Ridha, M. R., Rahayu, N., Rosvita, N. A., Setyaningtyas, D. E. The relation of environmental condition and container to the existence of the Aedes aegypti larvae in dengue haemorrhagic fever endemic areas in Banjarbaru. Epidemiology and Zoonosis Journal. Mei 2013. Vol. 4, No. 3: 133-137.

[17] Effendi, H. 2003. "Review Water Quality for Management of Resources and Aquatic Environment". Fifth print (in Bahasa: Telaah Kualitas Air bagi Pengelolaan Sumber Daya dan. Lingkungan Perairan. Cetakan Kelima) Yogyakarta: Kanisius.

[18] Thangamathi, P., Ananth, S., Kala, N., Maheswari, R., Gnanasoundrai, A., Nagamani, N. Seasonal variations and physicochemical characteristics of the habitats in relation to the density of dengue vector Aedes aegypti in Thanjavur, Tamil Nadu, India. International Journal of Science and Nature. 2014. Vol. 5 (2): 271-276.

[19] Madzlan F, Nazri CD, Chua ST, Nurmahirah Z. 2016. Breeding characteristic of Aedes mosquitoes in dengue risk area. Procedia-Social and Behavioral Sciences. 234 (2016): 164-172.

[20] Olayemi IK, Omalu ICJ, Famotele OL, Shegna SP, Idris B. Distribution of mosquito larvae in relation to physicochemical characteristics of breeding habitats in Minna, North Central Nigeria. RIF. 2010. Vol 1(1): 49-53.

[21] Yusuf M., Gentur Handoyo, Muslim, Sri Yulina Wulandari, dan Heriyoso Setiyono."Characteristics of Flow Patterns in Relation to Water Quality Conditions and Phytoplankton Abundance in the Waters of Karimunjawa Marine National Park Area (in Bahasa: Karakteristik Pola Arus Dalam Kaitannya dengan Kondisi Kualitas Perairan dan Kelimpahan Fitoplankton di Perairan Kawasan Taman Nasional Laut Karimunjawa”. Buletin Oseanografi Marina. Oktober 2012. vol. 1: 63 - 74.

[22] Salmin. Dissolved Oxygen (DO) and Biological Oxygen Needs (BOD) As One Indicator To Determine Water Quality (in Bahasa: Oksigen Terlarut (DO) Dan Kebutuhan Oksigen Biologi (BOD) Sebagai Salah Satu Indikator Untuk Menentukan Kualitas Perairan”. Oseana. Vol. XXX, Nomor 3, 2005: 21-26. ISSN 0216-1877. 